\title{
HEAT STRESS TOLERANCE ASSAYED IN FOUR WINE-PRODUCING GRAPEVINE VARIETIES USING A CYTOGENETIC APPROACH
}

\section{ANÁLISE DA TOLERÂNCIA AO STRESSE TÉRMICO EM QUATRO CASTAS PRODUTORAS DE VINHO USANDO UMA ABORDAGEM CITOGENÉTICA}

\author{
Ana Carvalho ${ }^{1,2^{*}}$, Fernanda Leal ${ }^{1,3}$, Manuela Matos ${ }^{1,3}$, José Lima-Brito ${ }^{1,2,3}$ \\ ${ }^{1}$ Biosystems and Integrative Sciences Institute - University of Tras-os-Montes and Alto Douro (BioISI-UTAD), University of Tras-os-Montes and \\ Alto Douro, Quinta de Prados, 5000-801 Vila Real, Portugal; \\ ${ }^{2}$ Centre for the Research and Technology of Agro-Environmental and Biological Sciences (CITAB), University of Tras-os-Montes and Alto \\ Douro, Quinta de Prados, 5000-801 Vila Real, Portugal; \\ ${ }^{3}$ Department of Genetics and Biotechnology, University of Tras-os-Montes and Alto Douro, Quinta de Prados, 5000-801 Vila Real, Portugal
}

*corresponding author: Tel: +351259350914; E-mail: anacar@utad.pt

(Received 12.06.2018. Accepted 19.07.2019)

\section{SUMMARY}

The degree of tolerance to heat stress (HS) differs among grapevine varieties. HS affects the duration and the regularity of the cell cycle in plants. The cytogenetic studies in grapevine are scarce, and the consequences of HS in the mitosis are barely known. This work intends to evaluate the consequences of induced HS in the mitotic cell cycle and chromosomes of four wine-producing varieties: Touriga Franca (TF), Touriga Nacional (TN), Rabigato and Viosinho using a cytogenetic approach. HS $\left(1 \mathrm{~h}\right.$ at $\left.42{ }^{\circ} \mathrm{C}\right)$ was induced in plants of the four grapevine varieties that grew in vitro for 11 months. Plants of the same varieties and with equal age were used as control (maintained in vitro at $25^{\circ} \mathrm{C}$ ). Three plants per variety and treatment (control and HS) were analysed. After HS, root-tips were collected in all plants and immediately fixed to be used for the preparation of mitotic chromosome spreads. In total, 6,116 root-tip cells were scored. Among the 5,973 dividing cells, 24.33\% showed different types of irregularities in all mitotic phases (prophase, metaphase, anaphase, and telophase). After HS, the mitotic index (MI) decreased in the varieties TF and Viosinho, and increased in TN and Rabigato, relatively to the control. However, the average values of MI did not show statistically significant differences $(p>0.05)$ among varieties, treatments and for the variety $\mathrm{x}$ treatment interaction. The percentage of dividing cells with anomalies (\%DCA) increased after HS in all varieties relatively to the control. The average values of \%DCA presented statistically significant differences $(p$ $<0.05$ ) only between treatments. As far as we know, this work constitutes the first cytogenetic evaluation of the HS effects in the mitotic cell cycle and chromosomes of grapevine using meristematic cells of root-tips. TN has been considered tolerant to various abiotic stresses (drought and excessive heat and light) based on other methodologies. TF and Viosinho have been referred as tolerant to abiotic stress without deeper studies available, and till the development of our investigation, the sensibility of Rabigato was unknown. Among the varieties analysed in this work, Rabigato revealed to be the less tolerant to HS. This research can be useful for selection of grapevine clones more tolerant to HS for commercialization and for the improvement of the economic sustainability.

\section{RESUMO}

O nível de tolerância ao stresse térmico (HS) difere entre as castas de videira. O HS afeta a duração e a normalidade do ciclo celular nas plantas. Os estudos citogenéticos em videira são escassos, e as consequências do HS na mitose não são inteiramente conhecidas. Este trabalho pretende avaliar as consequências de HS induzido no ciclo celular mitótico de quatro castas produtoras de vinho: Touriga Franca (TF), Touriga Nacional (TN), Rabigato e Viosinho usando uma abordagem citogenética. O HS ( $1 \mathrm{~h}$ a $42{ }^{\circ} \mathrm{C}$ ) foi induzido em plantas das quatro castas desenvolvidas in vitro durante onze meses. Plantas das mesmas castas e com a mesma idade foram usadas como controlo (mantidas in vitro a $25^{\circ} \mathrm{C}$ ). Três plantas por casta e tratamento (controlo e HS) foram analisadas. Após o HS, colheram-se raízes em todas as plantas e fixaram-se imediatamente as raízes para serem usadas na preparação de esfregaços cromossómicos. No total, contaram-se 6.116 células meristemáticas da raiz. De entre as 5.973 células em divisão, $24,33 \%$ apresentaram diferentes tipos de irregularidades em todas as fases da mitose (profase, metafase, anafase e telofase). Após HS, o índice mitótico (MI) diminuiu nas castas TF e Viosinho, e aumentou em TN e Rabigato, relativamente ao controlo. Contudo, os valores médios de MI não apresentaram diferenças estatisticamente significativas $(p>0,05)$ entre castas, tratamentos ou para a interacção casta $\mathrm{X}$ tratamento. A percentagem de células em divisão com anomalias (\%DCA) aumentou após HS em todas as castas comparativamente ao controlo. Os valores médios da \%DCA apresentaram diferenças estatisticamente significativas $(p<0,05)$ apenas entre tratamentos. Tanto quanto sabemos, este trabalho constitui a primeira avaliação citogenética dos efeitos do HS no ciclo celular e cromossomas mitóticos de videira usando células meristemáticas da raiz. A casta TN tem sido considerada tolerante a vários stresses abióticos (seca, calor e luz excessivos) com base noutras metodologias. TF e Viosinho têm sido referidas como tolerantes a stresse abiótico mas sem estudos aprofundados disponíveis, e até ao desenvolvimento da nossa investigação, a sensibilidade de Rabigato ao stresse abiótico era desconhecida. Entre as castas analisadas neste trabalho,

\section{1}

This is an Open Access article distributed under the terms of the Creative Commons Attribution License (http://creativecommons.org/licenses/by/4.0), which permits unrestricted use, distribution, and reproduction in any medium, provided the original work is properly cited. 
Rabigato revelou ser a menos tolerante ao HS. Esta investigação pode ser útil na seleção de clones de videira mais tolerantes ao HS para comercialização e para a melhoria da sustentabilidade económica.

Key words: abiotic stress, cytogenetics, mitosis, meristematic cells of root-tips, Vitis vinifera L..

Palavras-chave: stresse abiótico, citogenética, mitose, células meristemáticas da raiz, Vitis vinifera L.

\section{INTRODUCTION}

Portugal is the $9^{\text {th }}$ of 15 countries that exported the highest wine worth value during 2017, contributing for $2.5 \%$ of the worldwide wine exportation [http://www.worldstopexports.com/wine-exportscountry/]. The exportation of Portuguese wine in 2017 increased $7.5 \%$ (reaching the value of 777.9 $\mathrm{M})$ relative to 2016 [https://www.viniportugal.pt/Estatisticas]. The wines from the Douro Demarcated Region, including the fortified Port wine and the non-fortified wines, as well as those produced in the Demarcated Region of Vinhos Verdes, were the most exported in 2017 [https://www.ine.pt].

The Douro Valley region (North of Portugal), particularly, the Douro Superior sub-region, is dominated by a strong winter-summer contrast in both temperature and precipitation (Jones and Alves 2013). As in other grapevine growing areas, the wine and grape producers have adapted varieties and viticulture practices to keep harvests within preferred dates (van Leeuwen et al., 2008). However, the ongoing climate changes may induce future alterations in grapevine varieties selected for a specific region; scion - graft combinations; and/or viticulture management activities (Parker et al., 2013; Duchêne et al., 2016). Despite the usual growing of grapevine above its optimal temperature (Pereira et al., 2014), the forecasted global warming coupled with water and irradiation stresses will have an outermost relevance in viticulture by reducing grape yield and wine quality (Chaves et al., 2002), and in the winemaking sector, mainly in Europe, where the optimal grapevine growing areas will move northward (Fraga et al., 2013, 2015a,b).

Notwithstanding the interplay of various stressful environmental conditions during the grapevine life cycle, many authors considered that air temperature is the main determinant factor of timing and duration of the grapevine phenological states (Dalla Marta et al., 2010; Alves et al., 2013; Bonnefoy et al., 2013; Neumann and Matzarakis 2014; Bonada and Sadras 2015). Concerning the importance of genetics in the adaptation to viticulture under a changing environment and the implications of the air temperature in the vine and wine quality, it is relevant to understand the heat stress (HS) tolerance behaviour of economically important grapevine varieties.

HS highly limits plants growth and productivity (Huang et al., 2012), particularly in cool-season (C3) species (Xu et al., 2015), like grapevine. Therefore, short- and long-term measures need to be taken to cope with the climate change impacts on viticulture. One suitable long-term strategy to mitigate the negative consequences of high temperatures in viticulture will be the genetic improvement towards the selection of grapevine varieties more tolerant to HS. Cytogenetics is an important tool of plant genetic breeding, and it could be helpful in the selection of grapevine genotypes with that purpose (Pereira et al., 2014; Carvalho et al., 2018).

$V$. vinifera has 38 chromosomes $(2 \mathrm{n}=2 \mathrm{x}=38)$ with small size and similar length that may range between $0.8 \mu \mathrm{m}$ and $2.37 \mu \mathrm{m}$ (Patil and Patil 1992; Haas and Alleweldt 2000). The reduced length of the grapevine chromosomes limited the cytogenetic studies in this species for a long time (Haas et al., 1994). Nowadays, they can still be considered scarce when compared with other plant species. Most of the available cytogenetic studies performed in grapevine relied on the determination of the chromosome number in different Vitis species and $V$. vinifera varieties, karyotyping, physical location of ribosomal DNA loci and/or nucleolar organizer regions (NORs) positively stained with silver nitrate (Ag-NORs) or on the evaluation of the ribosomal RNA (rRNA) genes expression in different varieties and tissues (leaves and roots) (Haas et al., 1994; Haas and Alleweldt 2000; Pinto-Maglio et al., 2010; Pierozzi 2011; Pierozzi and Moura 2016; Castro et al., 2018). Other cytogenetic studies focused the meiotic behaviour of some grapevine varieties through the evaluation of pollen viability/ fertility and germination in natural and stressful conditions (Da Silva et al., 2001; Pereira et al., 2014).

The different plant organs respond to abiotic stresses with different molecular, cellular and metabolic mechanisms. In fact, the leaf grapevine transcriptome revealed that $8 \%$ of the transcripts are HS-responsive genes (Liu et al., 2012). More recently, transcriptomic data achieved in four table grapevine varieties indicated that $8 \%$ of the $V$. vinifera genome presents high genomic plasticity given by inter- 
varietal-specific regions that may vary in copy number or in sequence, constituting potential candidate genes responsible for phenotypic differences among varieties (Cardone et al., 2016). Differential tolerance to abiotic stress (heat, drought, and irradiation) was recently reported for some wineproducing grapevine varieties (Carvalho et al., 2015, 2016, 2017; Rocheta et al., 2016).

Among the abiotic stressful conditions, high temperature is one of the major factors affecting negatively plant growth, development, and productivity (Huang et al., 2012). Thus, the evaluation of its consequences on growing parts of plants such as roots may allow the extrapolation of the plant physiological and biochemical performance to short and long-term stress as reported by Heckenberger et al., (1998).

The root system plays a crucial role in the wholeplant adaptation to stress. Roots under stress may experience modifications in structure, growth, and function (Gowda et al., 2011; Atkinson and Urwin 2012; Ghosh and Xu 2014; Barrios-Masias et al., 2015). Previous studies were performed regarding a deeper understanding of how fine root structure and function may define differential drought resistance in grapevine rootstocks based on hydraulics physiology (Barrios-Masias et al., 2015). In other plant species, the root thermal tolerance was evaluated based on proteomics (Huang et al., 2012; Xu et al., 2015). As far as we know, the consequences of HS in the mitotic cell cycle and chromosomes of grapevine root-tips have never been studied.

Recently, our research group evaluated the consequences of HS in the leaf mitotic cell cycle and chromosomes of four wine-producing varieties and detected differential HS tolerance among them (Carvalho et al., 2018). These varieties are used as grafts but regarding their propagation in nurseries and following commercialization to wine producers, the knowledge of the effects of HS in the root cell cycle and chromosomes in early stages of development can provide valuable information about their HS tolerance when installed in the vineyard.

In the basis of all contexts here introduced, this work intends to study the effects of induced HS in the root mitotic cell cycle and chromosomes of four wineproducing varieties, in order to extrapolate about their HS tolerance based on a cytogenetic approach.

\section{MATERIAL AND METHODS}

\section{Plant material and HS induction}

In this work, we used the red wine-producing varieties Touriga Franca (TF) and Touriga Nacional $(\mathrm{TN})$, and the white wine-producing varieties Rabigato and Viosinho, that are cultivated since long ago in the Douro Demarcated Region (Denomination of Origin Douro) and belong to the list of varieties officially recommended for wine production in this region (Portaria $n^{\circ} .383 / 2017$ ).

The plants used in this work were propagated in vitro from aseptic micro-stems containing a single axillary bud. These explants were placed in solid M\&S basal medium (Murashige and Skoog 1962) pH 5.8, supplied with $2 \%$ sucrose without the addition of phytohormones. The propagation in vitro occurred under a photoperiod of $16 \mathrm{~h}$ light/ $8 \mathrm{~h}$ dark, light intensity of $300 \mu \mathrm{mol} \mathrm{m} \mathrm{m}^{-2} \mathrm{~s}^{-1}$, at $25{ }^{\circ} \mathrm{C}\left( \pm 1.0{ }^{\circ} \mathrm{C}\right)$, within a growth chamber Fitoclima 'Walk-in' model 20000E (Aralab) for 11 months. At this stage, the plants presented an average height of $12 \mathrm{~cm}$ with 8 to 10 full expanded leaves from the shoot apex to the basis (except for the first leaf at the shoot apex that it was not fully expanded). Six plants of each grapevine variety were used. The HS was induced to three plants per variety by applying a temperature of $42{ }^{\circ} \mathrm{C}$ provided by a homogeneous heat source during $1 \mathrm{~h}$ (HS treatment). Three control plants of each variety were kept in vitro at $25^{\circ} \mathrm{C}$ (control treatment).

Three root-tips with $1 \mathrm{~cm}$ length were collected per plant of each variety and treatment. The root-tips were immediately fixed in absolute ethanol and acetic acid $(3: 1, v / v)$ freshly prepared and used for the preparation of mitotic chromosome spreads using the squashing method as described by Lima-Brito et al., (1996).

The chromosome spreads were aged for $2 \mathrm{~h}$ at $60{ }^{\circ} \mathrm{C}$, dehydrated for $15 \mathrm{~min}$ on a series of ethanol solutions $(70 \%, 90 \%$, and $100 \%)$, air dried, counterstained with VectaShield ${ }^{\circledR}$ Mounting Medium with DAPI (Vector Laboratories, Peterborough, UK) and covered with a glass coverslip $24 \times 50 \mathrm{~mm}$ for further observation under a fluorescence microscope.

\section{Images capturing}

Images of interphase nuclei, mitotic cells, and chromosomes counterstained with DAPI were captured under a fluorescence microscope model Olympus BX41 (Olympus America Inc., Hauppage, $\mathrm{NY}$, USA) using an $\mathrm{XC10}$ charge-coupled device (CCD) digital camera (Olympus America, Inc., Hauppauge, NY, USA), and the software cellSens (Olympus Soft Imaging Solutions $\mathrm{GmbH}$, Münster, Germany). Images were prepared for printing using the software Adobe $\AA$ Photoshop 6.0 ${ }^{\circledR}$ (Adobe Systems, San Jose, California). 


\section{Cells scoring and statistical analyses}

Three preparations, corresponding to three different plants per variety and per treatment (control and HS), were analysed. Per preparation, interphase, normal and irregular dividing cells observed in a total of 50 observation fields were scored on the fluorescence microscope. The mitotic cell phases of all dividing cells were identified. The mitotic index (MI) [(number of dividing cells/ number of scored cells) $\times$ $100 \%$ ] and the percentage of dividing cells with anomalies (\%DCA) [(number of dividing cells with anomalies/ total number of dividing cells) $\times 100 \%$ ] were determined per variety and treatment.

All cytogenetic data are presented as mean values \pm standard error (S.E.) per variety (V), treatment (T) and variety $\mathrm{x}$ treatment $(\mathrm{V} \times \mathrm{T})$ interaction. The twoway analyses of variance (ANOVA), the post hoc Fisher's protected least significant difference (PLSD) test, and the equality of variances $\mathrm{F}$ test were performed with the software StatView for Windows version 5.0 (SAS Institute Inc. Copyright 1992-1998). The pairwise comparison of means achieved in the interactions $\mathrm{V} \times \mathrm{T}$ was performed using a post hoc Tukey test for the significance levels of $1 \%$ and $5 \%$ using the Microsoft Excel. The $p$-value significance of the statistical analyses performed for the different effects (V, $\mathrm{T}$ and $\mathrm{V} \times \mathrm{T}$ ) was established for probabilities lower than $0.1 \%(p<0.001), 1 \%(p<$ $0.01)$ and $5 \%(p<0.05)$.

\section{RESULTS AND DISCUSSION}

Table I summarises the statistical analyses performed for the average values of the number of dividing cells, MI (\%), and DCA (\%) for the effects grapevine variety $(\mathrm{V})$, treatment $(\mathrm{T})$ and variety $\mathrm{x}$ treatment $(\mathrm{V}$ $\mathrm{x} T$ ) interaction.

TABLE I

Number of scored dividing cells, mitotic index (MI) and percentage of dividing cells with anomalies (DCA) per grapevine variety (V), treatment (T) and for the interaction variety $\mathrm{x}$ treatment $(\mathrm{V} \times \mathrm{T})$.

Número de células em divisão contadas, índice mitótico (MI) e percentagem de células em divisão com anomalias (DCA) por casta de videira (V), tratamento (T) e para a interação casta x tratamento (V $\times T)$.

\begin{tabular}{|c|c|c|c|c|}
\hline & & \\
\hline & & Number of dividing cells & MI (\%) & DCA $(\%)$ \\
\hline \multirow{4}{*}{$\begin{array}{c}\text { Variety } \\
\text { (V) }\end{array}$} & $\mathrm{TF}$ & $259.67 \pm 37.03 \mathrm{a}$ & $94.04 \pm 2.21 \mathrm{~b}$ & $13.85 \pm 2.05 \mathrm{a}$ \\
\hline & $\mathrm{TN}$ & $259.33 \pm 70.75 \mathrm{a}$ & $86.00 \pm 8.81 \mathrm{a}$ & $26.06 \pm 9.53 \mathrm{~b}$ \\
\hline & Rabigato & $164.17 \pm 22.94 \mathrm{~b}$ & $89.09 \pm 4.31 \mathrm{a}$ & $25.83 \pm 7.27 b$ \\
\hline & Viosinho & $312.33 \pm 39.09 \mathrm{c}$ & $96.90 \pm 0.83 \mathrm{~b}$ & $23.54 \pm 3.31 \mathrm{~b}$ \\
\hline \multirow{2}{*}{$\begin{array}{l}\text { Treatment } \\
\text { (T) }\end{array}$} & Control & $232.17 \pm 33.05$ & $87.75 \pm 4.73 \mathrm{a}$ & $15.23 \pm 2.29 \mathrm{a}$ \\
\hline & HS & $265.58 \pm 35.96$ & $95.26 \pm 1.19 \mathrm{~b}$ & $29.41 \pm 5.12 b$ \\
\hline \multirow{8}{*}{$\mathbf{V} \times \mathbf{T}$} & $\mathrm{TF} x$ con trol & $257.67 \pm 57.78$ & $97.23 \pm 1.34$ & $12.26 \pm 3.36$ \\
\hline & $\mathrm{TF} \times \mathrm{HS}$ & $261.67 \pm 59.26$ & $90.84 \pm 3.51$ & $15.44 \pm 2.69$ \\
\hline & TN x control & $218.33 \pm 81.68$ & $74.74 \pm 16.14$ & $19.07 \pm 5.12$ \\
\hline & $\mathrm{TN} \times \mathrm{HS}$ & $300.33 \pm 129.14^{*}$ & $97.25 \pm 1.05^{*}$ & $33.05 \pm 19.47^{*}$ \\
\hline & Rabigato x control & $123.00 \pm 28.45$ & $80.72 \pm 4.48$ & $9.70 \pm 1.71$ \\
\hline & Rabigato x HS & $205.33 \pm 11.26^{*}$ & $97.46 \pm 1.61 *$ & $41.96 \pm 1.02 *$ \\
\hline & Viosinho $\mathrm{x}$ control & $329.67 \pm 45.51$ & $98.29 \pm 0.95$ & $19.91 \pm 6.11$ \\
\hline & Viosinho $\mathrm{x}$ HS & $295.00 \pm 72.57^{*}$ & $95.52 \pm 0.81$ & $27.17 \pm 2.08^{*}$ \\
\hline \multirow[t]{3}{*}{$p$-values } & $\mathbf{V}$ & $*$ & $*$ & $*$ \\
\hline & $\mathbf{T}$ & n.s. & $* * *$ & $*$ \\
\hline & $V \times T$ & * & $*$ & $*$ \\
\hline
\end{tabular}

Values are expressed as mean \pm standard error of three replicates. Mean values followed by different letters within the columns $\mathrm{V}$ and $\mathrm{T}$ are significantly different for $p \quad 0.05$. For the interactions V x T, the mean values of V x HS followed by asterisk $(*)$ are statistically different from the control of the same variety for $p<0.05$ by the Tukey test. Note: (n.s.) - not significant $(p>0.05),(*)-\operatorname{significant}(p \quad 0.05)$ and $(* * *)-$ highly significant $(p<0.001)$. 
The average number of dividing cells significantly differed $(p<0.05)$ among varieties and for the $\mathrm{V} \times \mathrm{T}$ interaction but no statistically significant differences $(p>0.05)$ were detected between treatments (Table I). The lowest mean number of dividing cells was presented by Rabigato (164.17) and the highest one by Viosinho (312.33) (Table I). Regarding the V x T interaction, the mean number of dividing cells significantly increased $(p<0.05)$ after HS relative to control in TN and Rabigato, and significantly decreased $(p<0.05)$ in Viosinho (Table I).

Concerning to the average percentage values of MI, we found statistically significant differences for the effects variety $(p<0.05)$, treatment $(p<0.001)$ and V $\mathrm{x} \mathrm{T}$ interaction $(p<0.05)$ (Table I). The highest average MI values were observed in varieties Viosinho and TF that significantly differed $(p<0.05)$ from Rabigato and TN that presented the lower average values (Table I). The average values of MI significantly increased $(p<0.05)$ after HS $(95.25 \%)$ relative to control $(87.75 \%)$ (Table I). In the $\mathrm{V} \times \mathrm{T}$ interaction, a non-significant $(p>0.05)$ reduction of the average value of MI was observed after HS comparatively to control in the varieties $\mathrm{TF}$ and Viosinho whereas in $\mathrm{TN}$ and Rabigato the mean value of MI significantly increased $(p<0.05)$ after HS (Table I).

The average percentage values of DCA revealed statistically significant differences $(p<0.05)$ for the effects variety, treatment and V x T interaction (Table I). Regarding the individual effect of variety, the highest average value of DCA was observed in TN $(26.06 \%)$ which did not differ statistically $(p>0.05)$ from those detected in Rabigato and Viosinho varieties (Table I). Instead, the lowest average value of DCA presented by TF (13.85\%) was significantly different $(p<0.05)$ from those of the remaining varieties (Table I). The mean percentage of DCA significantly increased $(p<0.05)$ after HS $(29.41 \%)$ relative to control $(15.23 \%)$ (Table I). Since the MI percentage calculation included normal and irregular dividing cells, the augmented average MI in TN and Rabigato after HS was accompanied by a significant increase $(p<0.05)$ of the mean percentage of DCA in these varieties $(33.05 \%$ and $41.96 \%$, respectively) and also in Viosinho (21.17\%) for the $\mathrm{V} \times \mathrm{HS}$ interaction relative to $\mathrm{V} x$ control interaction (Table I). In variety TF the increase of average percentage of DCA after HS was not statistically significant $(p>$ 0.05) (Table I).

The root-tip cells presented a higher average MI and a lower average percentage of DCA per variety relative to the mesophyll cells of the same grapevine varieties previously studied after HS exposure (Carvalho et al.,
2018). The higher MI in roots than leaves is observed not only upon stress but also in control plants. This fact can be explained by the direct development of roots from the root apical meristem that maintain stem cells and exhibit an indeterminate growth contrarily to leaves that have a finite period of growth and development, as explained by Ichihashi and Tsukaga (2015). Additionally, the lower number of mitotic cells in leaves and the higher exposure of these organs to HS (occurring in vitro and in natural conditions) explain the higher percentage values of DCA in leaves than in roots. Even though, the present and our previous work (Carvalho et al., 2018), allowed us to focus on the MI and DCA values to extrapolate about the grapevine varieties more tolerant to HS because such parameters are highly considered in cytological studies of evaluation of toxicity and different abiotic stresses in different plant species (Smertenko et al., 1997; Schuppler et al., 1998; Hanif et al., 2013; Pekol et al., 2016; Reis et al., 2018). Independently of the type of stress induced or plant species, several authors have been reported a reduction of the MI and an increase of the DCA in root-tips as a response to stress. Hence, grapevine varieties that upon HS showed the highest MI and the lowest DCA - indicating that most of the mitotic cells maintained their regularity - reveal higher tolerance.

Different types of irregularities were detected in the root-tip cells of all varieties and in both treatments (control and HS). However, in Figure 1 it is presented regular interphase and mitotic cells observed in the control treatment (Fig. 1a, c, e, i and k) for comparison with the irregularities found in the same phases of the cell cycle after HS induction (Fig. 1b, d, f-h, j and 1).

Few binucleate interphase cells were observed after HS (Fig. 1b). Binucleate cells occur due to phragmoplast disruption during cytokinesis (Giménez-Abián et al., 1998) and were previously explained as a consequence of the exposure to heavy metals by Frantzios et al. (2000) in wheat and by Nefic et al. (2013) in Allium cepa. Binucleate cells were previously observed in these grapevine varieties after heat acclimation $\left(3 \mathrm{~h}\right.$ at $\left.32^{\circ} \mathrm{C}\right)$ and recovery periods $\left(3 \mathrm{~h}\right.$ at $32{ }^{\circ} \mathrm{C}$ and $24 \mathrm{~h}$ at $\left.25^{\circ} \mathrm{C}\right)$ in leaf mesophyll cells (Carvalho et al., 2018).

The dividing cells presented anomalies such as chromatin stickiness in prophase and telophase (Fig. $1 \mathrm{~d}$ and 1) which is highly frequent through the mitotic cycle of cells exposed to different abiotic stresses, including HS (Pekol et al., 2016; Carvalho et al., 2018; Reis et al., 2018). C-metaphases (Fig. 1f) as well as misoriented and laggard chromosomes in metaphase (Fig. 1g), anaphase (Fig. 1j) and telophase 
(Fig. 1k) are probable consequences of chromatin stickiness and chromosomal mis-segregation. As explained before, HS can damage the organization, density, and integrity of the microtubules, compromising the cell division (Smertenko et al., 1997; Wahid et al., 2007) and the chromosomal segregation. In any species, the mitotic chromosomal mis-segregation can generate aneuploid daughter cells with an incorrect number of chromosomes causing chromosome instability and genomic alterations with short- and long-term effects (Santaguida and Amon 2015). The endoreduplicated cells (Fig. 1h) correspond to numeric chromosomal anomalies (polyploidy) caused by abnormal segregation, loss of chromosomes, delay (laggard chromosomes) or chromatin stickiness
(Nefic et al., 2013). Therefore, one type of chromosomal anomaly may induce other, explaining the observed anomalies in the dividing root-tips (Fig. 1). These anomalies were similar to those observed in the leaf mesophyll cells of TF, TN, Rabigato, and Viosinho exposed to HS (Carvalho et al., 2018). HS allows the production and accumulation of reactive oxygen species (ROS) formed due to excessive reductions during the respiratory electron transport that induce oxidative stress and damage cells, nucleic acids, lipids and proteins in plants (Apel and Hirt 2004; Gill and Tuteja 2010; Xu et al., 2015). The ROS damage the DNA strands increasing the probability of occurrence of chromosomal anomalies and affecting negatively the cell division (Smertenko et al., 1997; Wahid et al., 2007).
Interphase cells

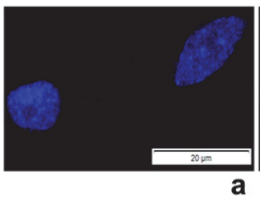

Metaphase cells

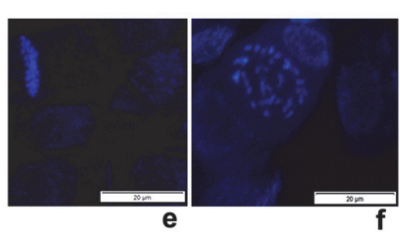

Anaphase cells

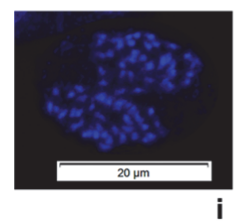

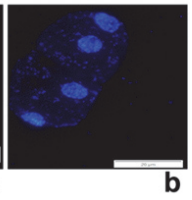

Prophase cells
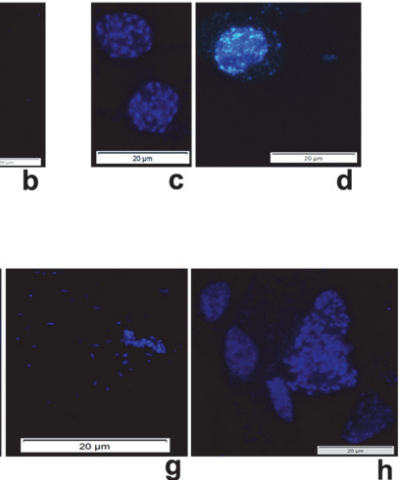

Telophase cells
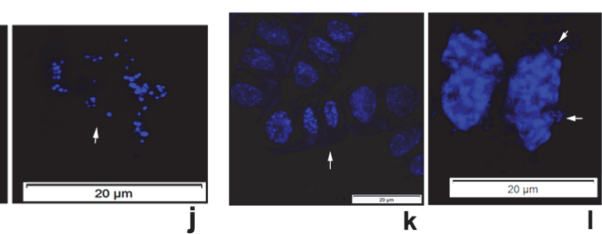

Figure 1 - Grapevine root-tip cells of the different varieties stained with DAPI, observed in control plants grown at $25^{\circ} \mathrm{C}(\mathrm{a}, \mathrm{c}, \mathrm{e}, \mathrm{i}$ and $\mathrm{k})$ and in plants subjected to HS for $1 \mathrm{~h}$ at $42^{\circ} \mathrm{C}$ (b, d, f-h, j and l), showing:. (a) normal interphase cells; (b) binucleate interphase cells; (c) normal prophase cells; (d) sticky prophase; (e) normal metaphase; (f) C-metaphase; (g) metaphase with disturbed chromosomal orientation at the cell equatorial plate and with laggard chromosomes; (h) polyploid metaphase (endoreduplicated cell); (i) normal and early anaphase; (j) late anaphase with laggard chromosomes (arrow); (k) normal telophase (arrow); and (l) sticky telophase with laggard chromosomes (arrows).

Células meristemáticas da raiz das diferentes castas de videira coradas com DAPI, observadas em plantas controlo crescidas a $25^{\circ} \mathrm{C}$ (a, $\mathrm{c}$, $e$, $i$ e

k) e em plantas que foram sujeitas ao $H S$ durante $1 \mathrm{~h}$ a $42^{\circ} \mathrm{C}(b, d, f-h, j$ e i), apresentando: (a) células interfásicas normais; (b) células interfásicas binucleadas; (c) células profásicas normais; (d) profase com stickiness; (e) metafase normal; (f) C-metafase; ( $g$ ) metafase com orientação cromossómica perturbada na placa equatorial da célula e com cromossomas laggard; (h) metafase poliplóide (célula endoreduplicada); (i) anafase normal e precoce; (j) anafase tardia e com cromossomas laggard (seta); ( $k$ ) telofase normal (seta); e (l) telofase com stickiness e cromossomas laggard (setas).

The irregular dividing root-tip cells observed in the control plants of all grapevine varieties (Tables I and II) may arose from the spontaneous occurrence of mitotic irregularities as a consequence of prolonged in vitro culture. Similar results were previously achieved in the mesophyll cells of control plants of the same varieties grown in vitro (Carvalho et al., 2018). 


\section{TABLE II}

Mean percentage values ( \pm standard error) of normal and irregular dividing cells in the different mitotic phases: prophase (Proph.), metaphase (Metaph.), anaphase (Anaph.) and telophase (Teloph.) per grapevine variety (V), treatment (T) and for the interaction variety $\mathrm{x}$ treatment (V $\mathrm{x} T$ ).

Valores médios de percentagem ( \pm erro padrão) de células em divisão normais e irregulares em diferentes fases mitóticas: profase (Proph.), metafase (Metaph.), anafase (Anaph.) e telofase (Teloph.) por casta de videira (V), tratamento (T) e para a interacção casta x tratamento (Vx $T$ ).

\begin{tabular}{|c|c|c|c|c|c|c|c|c|c|}
\hline & & \multicolumn{4}{|c|}{$\begin{array}{l}\text { Percentage of normal dividing cells }(\%) \text { in the } \\
\text { following mitotic phase: }\end{array}$} & \multicolumn{4}{|c|}{$\begin{array}{l}\text { Percentage of irregular dividing cells (\%) in the } \\
\text { following mitotic phase: }\end{array}$} \\
\hline & & Proph. & Metaph. & Anaph. & Teloph. & Proph. & Metaph. & Anaph. & Teloph. \\
\hline \multirow{8}{*}{ V } & \multirow{2}{*}{$\mathrm{TF}$} & $204.50 \pm$ & $7.17 \pm$ & $5.17 \pm$ & $7.83 \pm$ & $3.83 \pm$ & $23.83 \pm$ & $6.33 \pm$ & $1.50 \pm$ \\
\hline & & $31.92 \mathrm{~b}$ & $4.06 \mathrm{~b}$ & $1.79 \mathrm{~b}$ & $1.80 \mathrm{~b}$ & $1.62 \mathrm{a}$ & $2.73 \mathrm{a}$ & $1.41 \mathrm{a}$ & $0.85 \mathrm{a}$ \\
\hline & \multirow{2}{*}{$\mathrm{TN}$} & $210.33 \pm$ & $2.67 \pm$ & $2.33 \pm$ & $1.17 \pm$ & $2.83 \pm$ & $23.33 \pm$ & $15.33 \pm$ & $0.83 \pm$ \\
\hline & & $72.46 \mathrm{~b}$ & $1.41 \mathrm{a}$ & 0.49 a,c & $0.31 \mathrm{a}$ & $1.30 \mathrm{a}$ & $4.64 \mathrm{a}$ & $3.20 \mathrm{~b}$ & $0.54 \mathrm{a}$ \\
\hline & \multirow{2}{*}{ Rabigato } & $172.50 \pm$ & $7.17 \pm$ & $3.33 \pm$ & $13.50 \pm$ & $74.67 \pm$ & $30.50 \pm$ & $7.17 \pm$ & $3.50 \pm$ \\
\hline & & $20.42 \mathrm{a}$ & $3.51 \mathrm{~b}$ & $1.26 \mathrm{~b}, \mathrm{c}$ & $7.49 \mathrm{c}$ & $37.89 \mathrm{~b}$ & $10.65 \mathrm{c}$ & $3.52 \mathrm{~b}$ & $2.05 \mathrm{~b}$ \\
\hline & \multirow{2}{*}{ Viosinho } & $110.83 \pm$ & $2.50 \pm$ & $0.83 \pm$ & $1.50 \pm$ & $20.83 \pm$ & $22.83 \pm$ & $4.33 \pm$ & $0.50 \pm$ \\
\hline & & $12.71 \mathrm{a}$ & $1.34 \mathrm{a}$ & $0.54 \mathrm{a}$ & $0.67 \mathrm{a}$ & $9.21 \mathrm{c}$ & $8.59 \mathrm{a}$ & $0.80 \mathrm{a}$ & $0.34 \mathrm{a}$ \\
\hline \multirow{4}{*}{$\mathbf{T}$} & \multirow[b]{2}{*}{ Control } & $161.08 \pm$ & $8.92 \pm$ & $4.50 \pm$ & $9.25 \pm$ & $14.42 \pm$ & $24.00 \pm$ & $8.33 \pm$ & $1.67 \pm$ \\
\hline & & $23.67 \mathrm{a}$ & $2.28 \mathrm{~b}$ & $1.04 \mathrm{~b}$ & $3.97 \mathrm{~b}$ & $13.42 \mathrm{a}$ & 5.80 & 1.94 & 1.12 \\
\hline & \multirow{2}{*}{ HS } & $188.00 \pm$ & $0.83 \pm$ & $1.33 \pm$ & $2.75 \pm$ & $36.67 \pm$ & $26.25 \pm$ & $8.25 \pm$ & $1.50 \pm$ \\
\hline & & $35.31 \mathrm{~b}$ & $0.42 \mathrm{a}$ & $0.33 \mathrm{a}$ & $0.77 \mathrm{a}$ & $17.30 \mathrm{~b}$ & 4.12 & 2.27 & 0.45 \\
\hline \multirow{16}{*}{$V \times T$} & \multirow{2}{*}{ TF $\mathrm{x}$ control } & $193.33 \pm$ & $13.67 \pm$ & $8.67 \pm$ & $10.33 \pm$ & $0.33 \pm$ & $23.00 \pm$ & $8.33 \pm$ & $0.00 \pm$ \\
\hline & & 44.25 & 6.33 & 1.76 & 1.76 & 0.33 & 7.21 & 2.33 & 0.00 \\
\hline & \multirow[t]{2}{*}{ TF x HS } & $\begin{array}{l}215.67 \pm \\
5486 *\end{array}$ & $0.67 \pm$ & $1.67 \pm$ & $5.33 \pm$ & $\begin{array}{l}7.33 \pm \\
0.88 *\end{array}$ & $23.67 \pm$ & $\begin{array}{l}4.33 \pm \\
0.67 *\end{array}$ & $3.00 \pm$ \\
\hline & & $54.86^{*}$ & $0.33^{*}$ & $0.67^{*}$ & $2.60^{*}$ & $0.88^{*}$ & 7.45 & $0.67^{*}$ & $1.16^{*}$ \\
\hline & \multirow{2}{*}{ TN x Control } & $175.67 \pm$ & $4.33 \pm$ & $3.00 \pm$ & $1.00 \pm$ & $1.67 \pm$ & $22.00 \pm$ & $10.67 \pm$ & $0.00 \pm$ \\
\hline & & 77.19 & 2.60 & 0.58 & 0.58 & 0.88 & 3.22 & 3.67 & 0.00 \\
\hline & \multirow{2}{*}{$\mathrm{TN} \times \mathrm{HS}$} & $245.00 \pm$ & $1.00 \pm$ & $1.67 \pm$ & $1.33 \pm$ & $4.00 \pm$ & $25.67 \pm$ & $20.00 \pm$ & $1.67 \pm$ \\
\hline & & $138.17 *$ & $0.58 *$ & 0.67 & 0.33 & $2.52 *$ & 4.84 & $4.00^{*}$ & $0.88^{*}$ \\
\hline & \multirow{2}{*}{ Rabigato $\mathrm{x}$ control } & $168.00 \pm$ & $14.33 \pm$ & $5.33 \pm$ & $25.33 \pm$ & $54.00 \pm$ & $45.00 \pm$ & $11.00 \pm$ & $6.67 \pm$ \\
\hline & & 39.95 & 3.18 & 1.76 & 11.84 & 54.00 & 17.10 & 6.66 & 3.28 \\
\hline & \multirow{2}{*}{ Rabigato x HS } & $177.00 \pm$ & $0.00 \pm$ & $1.33 \pm$ & $1.67 \pm$ & $95.33 \pm$ & $16.00 \pm$ & $3.33 \pm$ & $0.33 \pm$ \\
\hline & & $21.63 *$ & $0.00^{*}$ & $0.88^{*}$ & $0.67^{*}$ & $61.92 *$ & $8.00^{*}$ & $1.67^{*}$ & $0.33^{*}$ \\
\hline & \multirow{2}{*}{ Viosinho x control } & $107.33 \pm$ & $3.33 \pm$ & $1.00 \pm$ & $0.33 \pm$ & $1.67 \pm$ & $6.00 \pm$ & $3.33 \pm$ & $0.00 \pm$ \\
\hline & & 26.93 & 2.33 & 1.00 & 0.33 & 0.67 & 1.00 & 0.88 & 0.00 \\
\hline & \multirow{2}{*}{ Viosinho $\mathrm{x}$ HS } & $114.33 \pm$ & $1.67 \pm$ & $0.67 \pm$ & $2.67 \pm$ & $40.00 \pm$ & $39.67 \pm$ & $5.33 \pm$ & $1.00 \pm$ \\
\hline & & $8.33^{*}$ & $1.67^{*}$ & $0.67^{*}$ & $0.88^{*}$ & $7.50^{*}$ & $9.21 *$ & $1.20^{*}$ & $0.58^{*}$ \\
\hline \multirow[t]{3}{*}{$p$-values } & $\mathbf{V}$ & $*$ & * & ** & $*$ & $*$ & $*$ & $*$ & * \\
\hline & $\mathbf{T}$ & $*$ & $* *$ & ** & $*$ & $*$ & n.s. & n.s. & n.s. \\
\hline & $\mathbf{V} \times \mathbf{T}$ & $*$. & * & $*$ & $*$ & $*$ & $*$ & $*$ & $* *$ \\
\hline
\end{tabular}

Values are expressed as mean \pm standard error of three replicates. Mean values followed by different letters within the columns $\mathrm{V}$ and $\mathrm{T}$ are significantly different for $p<0.05$. For the interactions $\mathrm{V} \times \mathrm{T}$, the mean values of $\mathrm{V} \times \mathrm{HS}$ followed by asterisk $(*)$ are statistically different from $\mathrm{V}$ $\mathrm{x}$ control of the same variety for $p<0.05$ by the Tukey test. Note: (n.s.) - not significant $(p>0.05),(*)-$ significant $(p<0.05)$ and $(* *)-$ very significant $(p<0.01)$.

Table II summarises the statistical analyses performed for the average number of normal and irregular dividing cells in the different mitotic phases, per grapevine variety, treatment and for the variety $\mathrm{x}$ treatment interaction

The average number of normal and irregular dividing cells in different mitotic phases presented statistically significant differences $(p<0.05)$ among varieties (Table II). In the normal mitotic cells, the mean number of prophases was the highest one in all varieties (Table II). Except for Rabigato that showed the highest mean number of irregular dividing cells in prophase, the remaining varieties presented a higher mean number of irregular cells in metaphase (Table II).
The average number of normal and irregular prophases increased significantly $(p<0.05)$ relatively to control after HS (Table II). The mean values of normal metaphases, anaphases and telophases also showed statistically significant differences $(p<0.05)$ between treatments (Table II). Overall, except for the average number of irregular metaphase, anaphase and telophase cells, all dividing cells showed statistically significant differences $(p<0.05)$ between treatments.

The average values of the number of normal and irregular dividing cells in different mitotic phases showed statistically significant differences $(p<0.05)$ for the variety $\mathrm{x}$ treatment interaction (Table II). For each variety, the number of normal and irregular prophases increased significantly $(p<0.05)$ in variety $\mathrm{x}$ HS interaction relatively to variety $\mathrm{x}$ control interaction (Table II). The significant increase in the 
number of prophase cells was also detected in the mesophyll cells of the same grapevine varieties after exposure to HS and also in control plants (Carvalho et al., 2018). Nevertheless, in this work, the average values of both normal and irregular prophases were higher than those reported by Carvalho et al. (2018) in the mesophyll cells. The increase of prophase cells upon different abiotic stresses was previously described in wheat (Pekol et al., 2016; Reis et al., 2018). In the particular case of HS, it was previously stated that exposure to high temperatures can cause spindle disturbance and polar deviation, which affects the chromosomal kinetics and induce prolonged prophase (Smertenko et al., 1997; Wahid et al., 2007; Nefic et al., 2013). Therefore, cell cycle arresting is an abiotic stress-responsive mechanism that extends the mitosis duration (Schuppler et al., 1998).

\section{CONCLUSIONS}

The predicted extreme environmental episodes of drought and excessive temperature will affect viticulture. Therefore, it is urgent to understand the behaviour of different grapevine varieties under such extreme conditions and assess their adaptive ability (Rocheta et al., 2016), to respond with the selection of more tolerant genotypes and proper viticultural practices to improve the economic sustainability under a changing environment.

As far as we know, this work constituted the first cytogenetic approach for HS tolerance evaluation in grapevine based on mitotic cell cycle analysis. Based on the present cytogenetic data it seems that the two white wine-producing varieties Rabigato and Viosinho are the most susceptible to HS exposure. This research may be useful for the selection of

\section{REFERENCES}

Alves F., Edlmann M., Costa J., Costa P., Macedo P., da Costa P.L., Symington C., 2013. Heat requirements and length of phenological stages. Effects of rootstock on red grape varieties at Douro Region. In: $18^{\text {th }}$ International Symposium GIESCO, Porto, Portugal, 7-11 July 2013.

Apel K., Hirt H., 2004. Reactive oxygen species: metabolism, oxidative stress, and signal transduction. Annu. Rev. Plant Biol., 55, 373-99.

Atkinson N.J., Urwin P.E., 2012. The interaction of plant biotic and abiotic stresses: from genes to the field. J. Exp. Bot., 63, 35233544

Barrios-Masias F.H., Knipfer T., McElrone A.J., 2015. Differential responses of grapevine rootstocks to water stress are associated with adjustments in fine root hydraulic physiology and suberization. J. Exp. Bot., 66, 6069-6078. genotypes with high tolerance to HS and therefore can be applied to grapevine varieties and clones micropropagated in vitro or propagated in nurseries prior to their commercialization and field installation. The use of HS tolerant genotypes can be in long-term the best strategy to face the environmental constraints caused by the actual scenario of climate changes that have been affecting viticulture, grape and wine quality.

\section{ACKNOWLEDGMENTS}

This work was supported by the projects "Vine and Wine Innovation Platform - INNOVINE\&WINE" (NORTE-01-0145-FEDER-000038, research line Viticulture) and "Integrative Research in Environment, Agro-Chain and Technology INTERACT” (NORTE-01-0145-FEDER-000017), research line "Fostering viticulture sustainability for Douro Valley: multidisciplinary efforts from field to wine - VitalityWine". The author AC acknowledges her postdoctoral fellowship BPD/UTAD/INNOVINE\&WINE/593/2016 attributed by the project INNOVINE\&WINE (NORTE-010145-FEDER-000038, research line Viticulture), and to FCT - Portuguese Foundation for the Science and Technology, her contract as researcher under the scope of the D.L. no. 57/2016 of 29 August and Law no. $57 / 2017$ of 19 July established with UTAD. The authors thank the projects UID/MULTI/04046/2019 and UID/AGR/04033/2019 (financed by the FCT), POCI-01-0145-FEDER-006958 (supported by FEDER/COMPETE/POCI _ - Operational Competitiveness and Internationalization Programme), and the COST ACTION "INDEPTH" (CA16212).

Bonada M., Sadras V.O., 2015. Review: critical appraisal of methods to investigate the effect of temperature on grapevine berry composition. Aust. J. Grape Wine Res., 21, 1-17.

Bonnefoy C., Quenol H., Bonnardot V., Barbeau G., Madelin M., Planchon O., Neethling E., 2013. Temporal and spatial analyses of temperature in a French wine-producing area: the Loire Valley. Int. J. Climatol., 33, 1849-1862.

Cardone et al. M.F., D'Addabbo P.D., Alkan C., Bergamini C., Catacchio CR, Anaclerio F, Chiatante G., Marra A., Giannuzzi G, Perniola R., Ventura M., Antonaccí D., 2016.Inter-varietal structural variation in grapevine genomes. Plant J., 88, 648-661.

Carvalho A., Leal F., Matos M., Lima-Brito J., 2018. Effects of heat stress in the leaf mitotic cell cycle and chromosomes of four wine-producing grapevine varieties. Protoplasma, 255, 1725-1740.

Carvalho L.C., Coito J.L., Colaço S., Sangiogo M., Amâncio S., 2015. Heat stress in grapevine: the pros and cons of acclimation. Plant Cell Environ., 38, 777-789.

Carvalho L.C., Coito J.L., Gonçalves E.F., Chaves M.M., 2016. Differential physiological response of the grapevine varieties 
Touriga Nacional and Trincadeira to combined heat, drought and light stresses. Plant Biol., 18, 101-111.

Carvalho L.C., Silva M., Coito J.L., Rocheta M.P., Amâncio S., 2017. Design of a custom RT-qPCR array for assignment of abiotic stress tolerance in traditional Portuguese grapevine varieties. Front. Plant. Sci., 8, 1835.

Castro C., Carvalho A., Pavia I., Leal F., Moutinho-Pereira J., Lima-Brito J., 2018. Nucleolar activity and physical location of ribosomal DNA loci in Vitis vinifera L. by silver staining and sequential FISH. Sci Hortic., 232, 57-62.

Chaves M.M., Pereira J.S., Maroco J., Rodrigues M.L., Ricardo C.P., Osório M.L., Carvalho I., Faria T., Pinheiro C., 2002. How plants cope with water stress in the field. Photosynthesis and growth. Ann. Bot., 89, 907-916.

Da Silva P.R., Bione N.C.P., Da Silva N., Pagliarini M.S., 2001. Meiotic behavior of the Brazilian table grape cultivar Rubi (Vitis vinifera) with a high proportion of seedless berries. Vitis, 40, 1-4.

Dalla Marta A., Grifoni D., Mancini M., Storchi P., Zipoli G., Orlandini S., 2010. Analysis of the relationships between climate variability and grapevine phenology in the Nobile di Montepulciano wine production area. J. Agric. Sci., 148, 657-666.

Duchêne E., 2016. How can grapevine genetics contribute to the adaptation to climate change? OENO One, 50, 3, 113-124.

Fraga H., Malheiro A.C., Moutinho-Pereira J., Santos J.A., 2013. Future scenarios for viticultural zoning in Europe: ensemble projections and uncertainties. Int. J. Biometeorol., 57, 909925.

Fraga H., Malheiro A.C., Moutinho-Pereira J., Santos J.A., 2015a. Agriculture and Climate Change - Adapting Crops to Increased Uncertainty (AGRI 2015). Grapevines growing under future RCP scenarios in Europe. Procedia Environ. Sci., 29, 20.

Fraga H., Santos J.A., Malheiro A.C., Oliveira A.A., MoutinhoPereira J., Jones G.V., 2015b. Climatic suitability of Portuguese grapevine varieties and climate change adaptation. Int. J. Climatol., doi: $10.1002 /$ joc. 4325

Frantzios G., Galatis B., Apostolakos P., 2000. Aluminium effects on microtubule organization in dividing root-tip cells of Triticum turgidum. I mitotic cells. New Phytol., 145, 211-224.

Ghosh D., Xu J., 2014. Abiotic stress responses in plant roots: a proteomics perspective. Front. Plant Sci., 5, Article 6, 1-13. doi: 10.3389/fpls.2014.00006.

Gill S.S., Tuteja N., 2010. Reactive oxygen species and antioxidant machinery in abiotic stress tolerance in crop plants. PPB/ Societe francaise de physiologie vegetale, 48, 909-30.

Giménez-Abián M.I., Utrilla L., Cánovas J.L., Giménez-Martin G., Navarrete M.H., De la Torre C., 1998. The positional control of mitosis and cytokinesis in higher-plant cells. Planta, 204, 37-43.

Gowda V.R.P., Henry A., Yamauchi A., Shashidhar H.E., Serraj R., 2011. Root biology and genetic improvement for drought avoidance in rice. Field Crops Res., 122, 1-13.

Haas H.U., Alleweldt G., 2000. The katyotype of grapevine (Vitis vinifera L.). ISHS Acta Hortic., 528, VII Int. Symp. Grapevine Genet. Breed. doi: 10.17660/ActaHortic.2000.528.33

Haas H.U., Budahm H., Alleweldt G., 1994. In situ hybridization in Vitis vinifera $\mathrm{L}$.. Vitis, 33, 251-252.

Hanif F., Afshan S., 2013. Evaluating the response of wheat genotypes to salinity stress. Asian J. Agric. Sci., 5, 126-129.
Heckenberger U., Roggatz U., Schurr U., 1998. Effect of drought stress on the cytological status in Ricinus communis. J. Exp. Bot., 49, 181-189.

Huang B., Rachmilevitch S., Xu J., 2012. Root carbon and protein metabolism associated with heat tolerance. J. Exp. Bot., 63, 34553465 .

Ichihashi Y., Tsukaya H., 2015. Behavior of leaf meristems and their modification. Front. Plant Sci., 6, 1060 . doi: 10.3389/fpls.2015.01060.

Jones G., Alves, F., 2013. The climate of the Douro: structure, trends and mitigation and adaptation responses to a changing climate. In: Proc. $18^{\text {th }}$ Int. Symp. GIESCO, 7-11 July 2013, Porto, Portugal.

Lima-Brito J., Guedes-Pinto H., Harrison G.E., Heslop-Harrison J.S., 1996. Chromosome identification and nuclear architecture in triticale $\mathrm{x}$ tritordeum $\mathrm{F}_{1}$ hybrids. J. Exp. Bot., 47, 583-588.

Liu G.T.,Wang J.F., Cramer G., Dai Z.W., Duan W., Xu H.G.,Wu B.H., Fan P.G., Wang L.J., Li S.H., 2012. Transcriptomic analysis of grape (Vitis vinifera L.) leaves during and after recovery from heat stress. BMC Plant Biol., 12, 174-183.

Murashige T., Skoog F., 1962. A revised medium for rapid growth and bioassays with tobacco tissue cultures. Physiol. Plant, 15, $473-$ 497.

Nefic H., Musanovic J., Metovic A., Kurteshi K., 2013. Chromosomal and nuclear alterations in root tip cells of Allium cepa L. induced by alprazolam. Med. Arh., 67, 388-392.

Neumann P.A., Matzarakis A., 2014. Estimation of wine characteristics using a modified Heliothermal Index in BadenWurttemberg, SW Germany. Int. J. Biometeorol., 58, 407-415.

Parker A., de Cortázar-Atauri I.G., Chuine I., Barbeau G., Bois B., Boursiquot J.-M., Cahurel J.-Y., Claverie M., Dufourcq T., Gény L., Guimberteau G., Hofmann R.W., Jacquet O., Lacombe T., Monamy C., Ojeda H., Panigai L., Payan J.-C., Lovelle B.R., Rouchaud E., Schneider C., Spring J.-L., Storchi P., Tomasi D., Trambouze W., Trought M., van Leeuwen C., 2013. Classification of varieties for their timing of flowering and veraison using a modelling approach: a case study for the grapevine species Vitis vinifera L. Agric. Forest Meteorol., 180, 249-264.

Patil S.G., Patil V.P., 1992. Karyomorphology of Vitis vinifera, $V$. rotundifolia and their hybrid. Cytologia, 57, 91-95.

Pekol S., Baloğlu M.C., Çelik Altunoğlu Y., 2016. Evaluation of genotoxic and cytotoxic effects of environmental stress in wheat species with different ploidy levels. Turk. J. Biol., 40, 580-588.

Pereira H.S., Delgado M., Avó A.P., Barão A., Serrano I., Viegas W., 2014. Pollen grain development is highly sensitive to temperature stress in Vitis vinifera. Aust. J. Grape Wine Res., 20, 474-484

Pierozzi N.I., 2011. Karyotype and NOR-banding of mitotic chromosomes of some Vitis L. species. Rev. Bras. Frutic., Jaboticabal - SP, E, 564-570.

Pierozzi N.I., Moura M.F., 2016. Karyotype analysis in grapevines. Rev. Bras. Frutic., Jaboticabal - SP, 38, 213-221.

Pinto-Maglio C.A.F., Pommer C.V., Pierozzi N.I., 2010. Giemsa staining and fluorescent banding in some Vitis L. species. Caryologia, 63, 339-348.

Portaria $n^{\circ} .383 / 2017$, Diário da República, 1. ${ }^{\text {a }}$ série - N. ${ }^{\circ} 243$ - 20 de dezembro de 2017, Agricultura, Florestas e Desenvolvimento Rural, pp. 6659-6660 (In Portuguese) 
Reis S., Pavia I., Carvalho A., Moutinho-Pereira J., Correia C., Lima-Brito J., 2018. Seed priming with Iron and Zinc in bread wheat: effects in germination, mitosis and grain yield. Protoplasma, 255, 1179-1194.

Rocheta M., Coito J.L., Ramos M.J.N., Carvalho L., Becker J.D., Carbonell-Bejerano P., Amâncio S., 2016. Transcriptomic comparison between two Vitis vinifera $\mathrm{L}$. varieties (Trincadeira and Touriga Nacional) in abiotic stress conditions. BMC Plant Biol., 16, 224.

Santaguida S., Amon A., 2015. Short- and long-term effects of chromosome mis-segregation and aneuploidy. Nat. Rev. Mol. Cell Biol., 16, 473-485.

Schuppler U., He P.-H., John P.C.L., Munns R., 1998. Effect of water stress on cell division and cell-division-cycle 2-like cellcycle kinase activity in wheat leaves. Plant Physiol., 117, 667-678.
Smertenko A., Dráber P., Viklický V., Opatrný Z., 1997. Heat stress affects the organization of microtubules and cell division in Nicotiana tabacum cells. Plant Cell Environ., 20, 1534-1542.

van Leeuwen C., Garnier C., Agut C., Baculat B., Barbeau G., Besnard E., Bois B., Boursiquot J.-M., Chuine I., Dessup T., Dufourcq T., Garcia-Cortazar I., Marguerit E., Monamy C., Koundouras S., Payan J.-C., Parker A., Renouf V., RodriguezLovelle B., Roby J.-P., Tonietto J., Trambouze W., 2008. Heat requirements for grapevine varieties are essential information to adapt plant material in a changing climate. In: Proc. $7^{\text {th }}$ Int. Terroir Cong., Changins, Switzerland (Agroscope Changins-Wädenswil: Switzerland), pp. 222-227.

Wahid A., Gelani S., Ashraf M., Foolad M., 2007. Heat tolerance in plants: an overview. Environ. Exp. Bot., 61, 199-223.

Xu Y., Burgess P., Huang B., 2015. Root antioxidant mechanisms in relation to root thermotolerance in perennial grass species contrasting in heat tolerance. PLOS ONE, 10(9), e 0138268. 